\title{
Postmarital Residence and Biological Variation at Pueblo Bonito
}

\author{
Michael A. Schillaci ${ }^{1 *}$ and Christopher M. Stojanowski \\ ${ }^{1}$ Department of Anthropology, University of New Mexico, Albuquerque, New Mexico 87131 \\ ${ }^{2}$ Department of Anthropology, Florida State University, Tallahassee, Florida 32306-4531
}

KEY WORDS social organization; Chaco Canyon; Pueblo Indian; determinant ratio analysis

\begin{abstract}
Although the social organization of many of the present-day pueblos of the American Southwest is well-described in the anthropological literature, many aspects of prehistoric Puebloan social organization have received limited attention since initial investigations of postmarital residence in the 1960s and 1970s. This paper examines postmarital residence at the Chaco Canyon great house of Pueblo Bonito, using biological data. Our findings are inconsistent with the previously well-accepted hypothesis that the Pueblo II and Pueblo III occupants of the San Juan Basin conformed to a socially prescribed pattern of matrilocal residence with matrilineal
\end{abstract}

It is difficult to overstate the significance of investigating the social organization of prehistoric communities to our understanding of the development of complex societies. Social organization is integral to the structuring of social relations within and among regional communities (Eggan, 1950). Certain components of this organization, such as kin structure and postmarital residence, provide culturally defined systems representing the foundation for social integration. Postmarital residence is particularly important because it provides for regional integration by incorporating into a community outside members from within a regional network. As such, postmarital residence can be important for developing and maintaining trade networks and defense alliances, and promoting solidarity both within and among potentially diverse communities (Schillaci and Stojanowski, 2002).

Because of the potential significance of withinand among-community integration to the development of the sociopolitical and even economic complexity of past cultures, investigating components of social organization such as postmarital residence is of great interest to archaeologists. Biological anthropology plays an important role in the study of prehistoric social organization through quantitative analyses of sex-specific within- and between-community phenotypic variation. Such analyses allow inferences about patterns of prehistoric sex-specific migration based on what is known about social organization and biological variation among present- descent. Univariate variance differences for nine craniometric variables indicate a pattern of increased female variability consistent with patrilocal/bilocal residence. The results of multivariate determinant ratio analyses are in agreement with the univariate results, suggesting the possibility of a patrilocal or bilocal residence preference at Pueblo Bonito. These findings are inconsistent with the notion that the female-based system of matrilocal residence with matrilineal descent observed among the present-day Western Pueblos was the ancestral Anasazi condition. Am J Phys Anthropol 120:1-15, 2003.

๑) 2003 Wiley-Liss, Inc.

day groups, and on quantitative genetics models (see Konigsberg, 1988).

Although the scale and complexity of the Chaco Canyon pueblos and communities of the American Southwest (ca. AD 890-1140), as well as the regional system associated with them, have been subjects of considerable study (e.g., Akins, 1986; Akins and Schelberg, 1984; Altschul, 1978; Lekson, 1988; Schelberg, 1984; Sebastian, 1992; Vivian, 1990), aspects of social organization such as postmarital residence have not received much attention in the literature (but see Peregrine, 2001; Peregrine and Ember, 2002; Schillaci and Stojanowski, 2000, 2002). The purpose of the present research is to investigate postmarital residence at the large prehistoric Chacoan great house of Pueblo Bonito. Specifically, we investigate postmarital residence using biological data collected from skeletal samples recovered during the excavations of Pueblo Bonito by George Pepper in the late 1890s and by Neil Judd in the $1920 \mathrm{~s}$. We briefly review previous attempts to reconstruct postmarital residence at prehistoric

\footnotetext{
*Correspondence to: Michael A. Schillaci, Department of Anthropology, University of New Mexico, Albuquerque, NM 87131.

E-mail: schillac@unm.edu
}

Received 28 September 2000; accepted 20 May 2002.

DOI 10.1002/ajpa.10147 


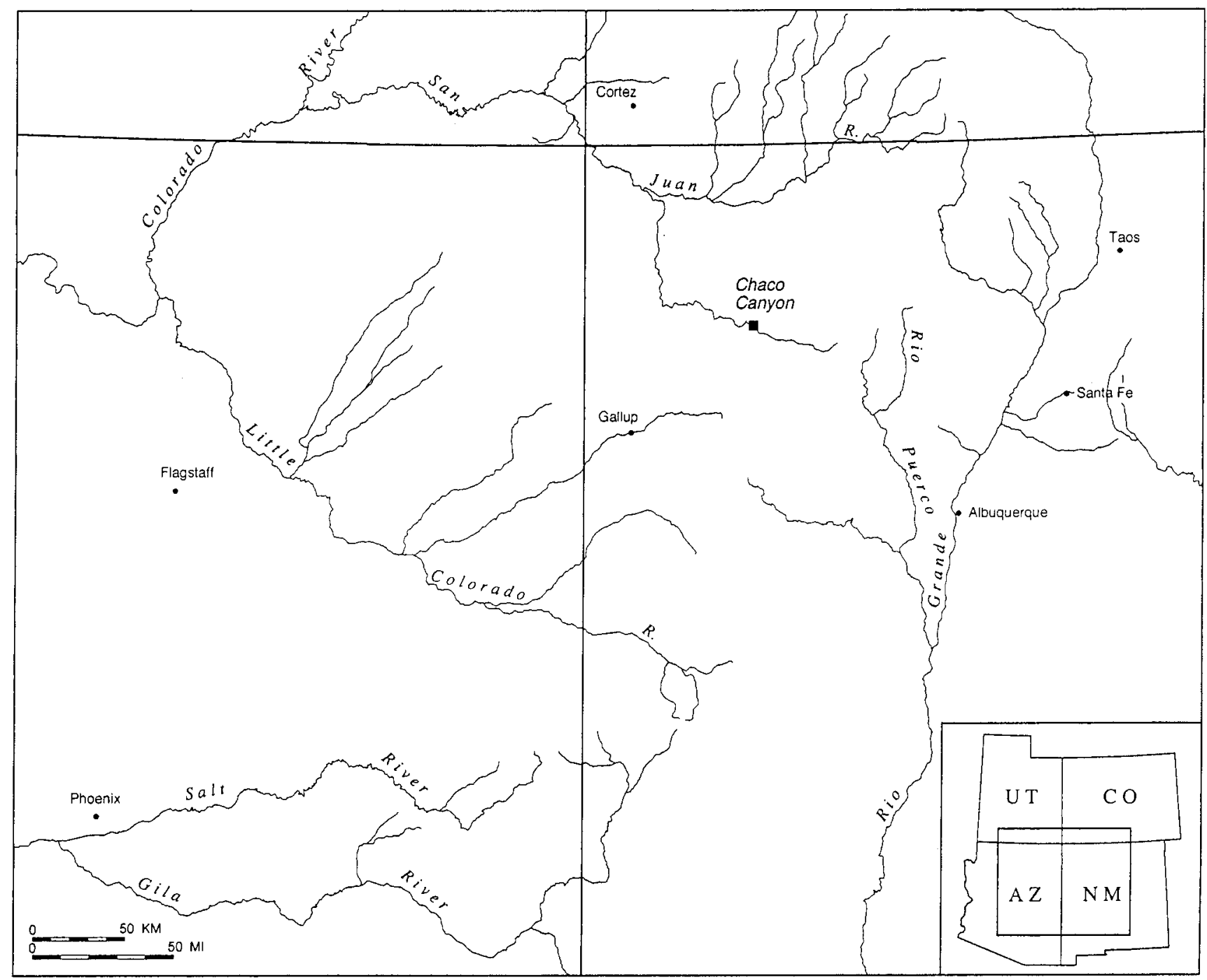

Fig. 1. Regional map showing location of Chaco Canyon.

Southwestern communities using archaeological and ethnographic data, as well as describe the theoretical and methodological assumptions associated with biologically based studies of prehistoric social organization. The results of our analysis are then presented within the context of current perspectives on prehistoric social organization in the Southwest.

\section{BACKGROUND}

The great houses of Chaco Canyon formed the core of a complex regional sociopolitical system integrating many Pueblo Indian communities within the San Juan basin and surrounding areas of the American Southwest during the Pueblo II and early Pueblo III periods (AD 890-1140) (Fig. 1). This regional system is largely defined archaeologically by compelling similarities in material culture and architecture among outlying Chacoan communities, and by a network of roads radiating out of Chaco Canyon connecting these outlying communities with the core (Kincaid, 1984; Nials et al., 1987; Roney,
1992; Vivian, 1997a, b). The sociopolitical organization of Chaco culture has been defined variously as a matrilineal-based corporate oriented polity (Peregrine, 2001), a rank society (Grebinger, 1973), a chiefdom (Martin and Plog, 1973), an emergent sodality-based polity (Ware, 2001), and a system comprised both of corporate lineages and nonexogamous moieties (Vivian, 1970). Despite this panoply of descriptors, there is a general consensus that Chacoan social organization was hierarchical, distinguishing it from egalitarian societies (but see Sebastian, 1991; Toll, 1985; Vivian, 1989).

\section{The site: Pueblo Bonito}

Architecture and social complexity. Pueblo Bonito was the largest of the great houses of Chaco Canyon, standing 4 or 5 stories high with over 650 rooms (Bernardini, 1999, p. 448; Lekson, 1986) (Fig. 2 ). Construction of this monumental masonry pueblo began around $\mathrm{AD} 890$ and lasted until sometime around AD 1130 (Windes and Ford, 1996). The 


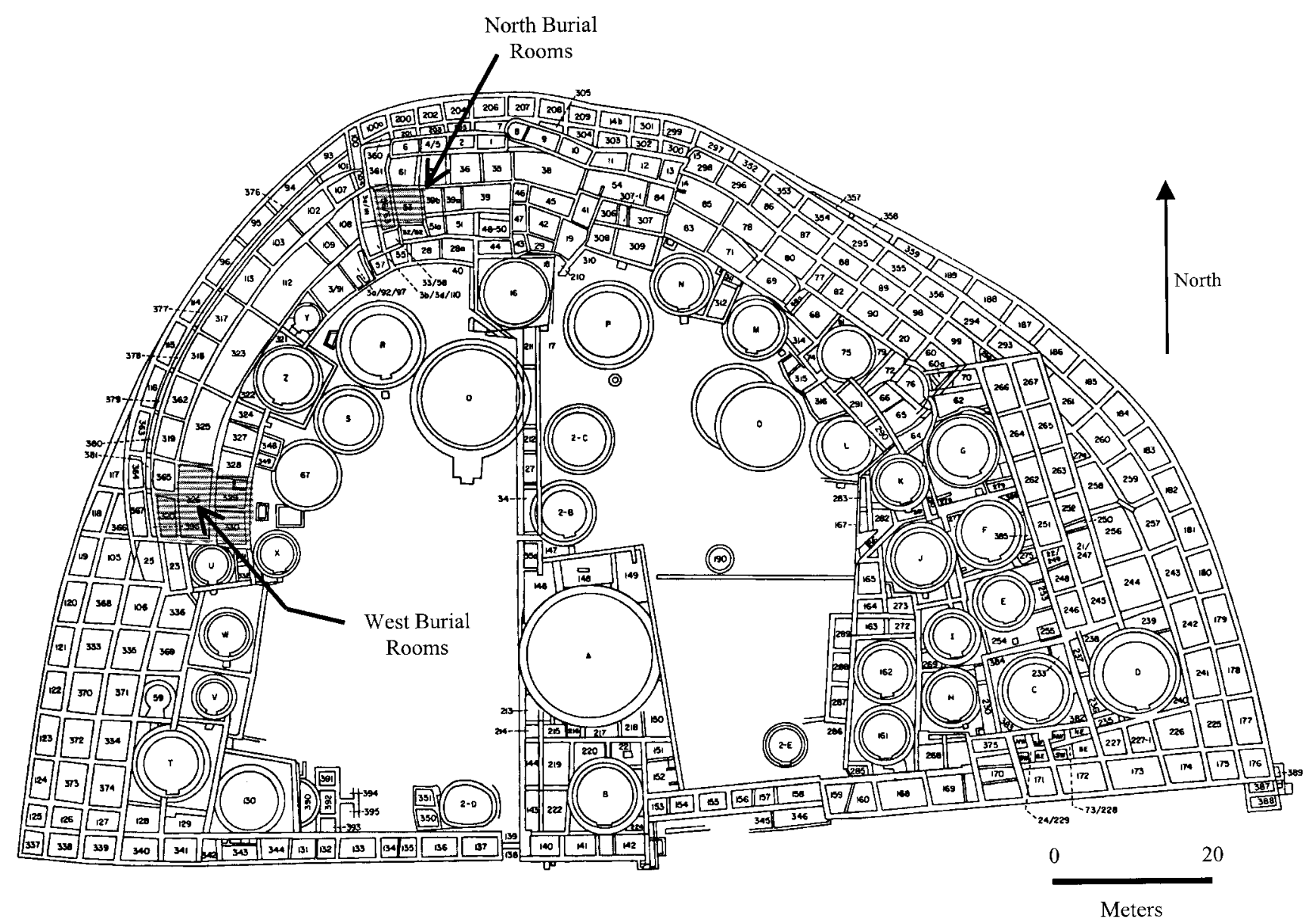

Fig. 2. Plan-view map of Pueblo Bonito, AD 890-1129. Burial rooms are indicated by shading.

impressive size of Pueblo Bonito, and its centralized location within Chaco Canyon, suggest it was likely an important center within the Chacoan regional system. The relatively low frequency of domestic floor features such as hearths indicates that Pueblo Bonito may not have been solely domestic or residential, but also held communal or perhaps religious importance for communities both within and outside Chaco Canyon (see Bernardini, 1999; Bustard, 1999; Lekson, 1986; Windes, 1984). The presence of hearths and other domestic floor features such as heating pits and grinding bins in over 42 rooms indicates, however, that there was a small resident population (see Bernardini, 1999; Windes, 1984).

The presence of smaller pueblos, termed "small houses," associated with the larger great houses within the Chacoan regional system, has been interpreted as evidence of two distinct social groups with corresponding differences in social organization (Vivian, 1970, 1989, 1990; but see Altschul, 1978; Grebinger, 1973), or as a system-wide pattern of site-size hierarchy indicative of sociopolitical complexity (Powers, 1984; Sebastian, 1992; Schelberg, 1984). In addition to obvious differences in structure size between small and great houses, differences in construction and how space is organized within these structures are also evident (Bustard, 1999). This architectural differentiation is viewed by at least one researcher (Sebastian, 1992) as the likely product of social or functional specialization indicative of an increased level of social complexity and a centralized political leadership. The extensive network of roads and the obvious requirement of organized labor to construct these roads, and the massively built monumental public architecture of the great houses (see Lekson, 1984), would seem to support this claim of increased sociopolitical complexity associated with Chacoan culture.

Community structure and mortuary context. Judd (1925) was the first to suggest that there were two separate populations at Pueblo Bonito, based on his evaluation of material culture and architecture (also see Judd, 1954). He labeled these populations "Old Bonitans" and "Late Bonitans," with the Old Bonitans being the original builders and occupants of the pueblo (but see Vivian 1956, 1970). The Late Bonitans were described by Judd (1954) as being newcomers to the pueblo with a recognizably distinct material culture and method of room construction. The presence of two distinct groups within this resident population at Pueblo Bonito is also sug- 
gested by the results of several biologically based analyses, using skeletal samples excavated from two burial plots, or clusters, within the pueblo (Akins, 1986; Schillaci and Stojanowski, 2002; Schillaci et al., 2001).

The burials at Pueblo Bonito are concentrated into two relatively discrete clusters of contiguous burial rooms, corresponding to the two distinct populations described earlier (see Akins 1986). The northern burial cluster was excavated by Pepper $(1909,1920)$ and Morehead in the late 1800s, while the western cluster was excavated by Judd (1954) in the 1920s (Fig. 2) (for a historical review, see Mathien, 2001). While it is impossible to determine if these two populations were absolutely contemporaneous without destructive testing of the skeletal remains, a review of the associated mortuary ceramic remains described by Akins (1986, p. 161-162) suggests that it is not unreasonable to assume these two distinct samples were largely contemporaneous (but for a detailed discussion of burial context and taphonomy, see Akins, 1986; Turner and Turner, 1999).

It is important to note that these burial clusters occur within a portion of the pueblo that had fallen into disuse. Bodies were interred in rooms with accumulated trash and building debris. Although these clusters likely represent group-specific geographically distinct burial plots or cemeteries, their geographic locations (i.e., west and north) do not necessarily correspond to the location of residence within the pueblo. Based on the distribution of domestic floor features within the pueblo (see Fig. 5.2 in Windes, 1984), two areas of habitation are apparent: one east of the north/south-oriented row of rooms bisecting the pueblo, and one west (see Fig. 2). Assuming that the west burial cluster is associated with the western habitation rooms, it is possible that the north burial cluster is associated with the eastern habitation rooms. It is likely that the location of the north burial cluster is a product of room disuse and deterioration in that portion of the pueblo, providing the opportunity for occupants of the eastern habitation rooms to bury their relatives within the walls of the pueblo.

Population origins and affinities. The population origin(s) of Chaco Canyon communities such as Pueblo Bonito has been a subject of interest for southwestern archaeologists. Although myriad models exist for the origin of Chaco populations, three are commonly discussed in the literature (reviewed in Vivian, 1990). The first describes an in situ development of existing Basketmaker III (AD 500-700) groups originally derived from larger populations to the north in the La Plata area of southwestern Colorado (Vivian, 1989, 1990). The second model includes a later ( $\mathrm{AD} 700-900)$ migration from the south by Cibolan groups from the Zuni area, and subsequent aggregation with resident La Plata groups (Vivian, 1989). The third model describes a migration by Mesoamerican groups or traders (Frisbie, 1978, 1980; Kelley and Kelley, 1975).

Of these, the second model is best supported by the archaeological record. The presence of northern La Plata groups in Chaco Canyon during the Basketmaker III period is suggested by the predominance of polished and unpolished La Plata black-on-white (for a description, see Lister and Lister, 1978) decorated ceramics at early habitation sites (Toll and McKenna, 1997; Vivian, 1990). The appearance of early Cibolan white-ware ceramic types such as Kiatuthlana and early Red Mesa black-on-white (for a description, see Lister and Lister, 1978) during the subsequent Pueblo I period in Chaco Canyon (Toll and McKenna, 1997) suggests either heavy influence or population movement by southern Cibolan groups. Although it is difficult to determine if the resident La Plata peoples were displaced by this migration, aggregation is suggested by the presence of the site-size hierarchy discussed earlier, as well as by the presence of two phenotypically distinct populations (Akins, 1986; Schillaci et al., 2001).

The third model describing migration by traders from Mexico is based on the presence of material culture common to both prehistoric Mexican groups and Chacoan culture. Items found at Chacoan sites such as copper bells, olivella shells, and macaws suggest that trade likely existed between Mexico and the Chacoan regional system (Mathien, 1997). Mexican influence is also suggested by the largescale public architecture seen at Chacoan great houses, as well as a number of other architectural traits (for a discussion, see Lekson, 1999, p. 89-94). In addition, human dental modification similar to that observed on presumed elite burials from southern Mexico is present on one Pueblo Bonito burial, supporting the notion of a Mexican presence at Chaco Canyon (Turner and Turner, 1999).

Although trade with Mexico, or even the presence of several traders, or pochteca, from southern Mexico, seems possible, there does not seem to be any strong evidence of substantial population movement from Mexico into Chaco Canyon (see Reyman, 1971, p. 17-22). Akins (1986) failed to identify any phenotypic outliers potentially representing Mexican pochteca, using a discriminant analysis of craniometric data from Chaco Canyon skeletal samples. Furthermore, results from recent research examining the craniometric variation between prehistoric Southwest site samples indicate that both populations at Pueblo Bonito have strong biological affinities with other site samples in the Southwest and comparatively little affinity with a southern Mexican sample included as an outgroup (see Schillaci et al., 2001).

Several studies examining the biological affinities of Pueblo Bonito with later Pueblo IV/Historic period (ca. $\mathrm{AD}$ 1300-1720) skeletal samples, using model-free analyses of craniometric data, described close relationships with ancestral Tewa-speaking populations to the east (Schillaci et al., 2001; Schil- 
laci and Stojanowski, 2002), with historic Hopi people to the west (Table 3 in El-Najjar, 1978), and with the ancestral Zuni community of Hawikku in westcentral New Mexico (Seltzer, 1944). Corruccini (1972) found Pueblo Bonito to be morphometrically more closely related to the ancestral Zuni and the ancestral Tewa populations than either of these later populations are to each other, a result somewhat surprising, given the contemporaneity of these two ancestral populations. The close minimum genetic relationships between the populations at Pueblo Bonito and temporally later ancestral Zuni and Tewa communities are presumably the product of gene flow or population movement from the Chaco regional system to these areas during the Pueblo II/Pueblo III period (ca. AD 890-1140).

Population size. Population estimates for Pueblo Bonito vary widely in the literature, depending on whether a residential function or some other social or ceremonial function is assumed for this Chacoan great house. Large population estimates ranging between 500 (Drager, 1976) and 1,200 (Pierson, 1949) have been based on the assumption that Pueblo Bonito served a primarily residential function (see also Hayes, 1981; Judd, 1954). More recent estimates, however, derived from architectural evidence suggesting Pueblo Bonito served a largely (but not entirely) social or ceremonial function, range between a maximum momentary population of 72 (Bernardini, 1999) and 100 (Windes, 1984) people. These lower population estimates (which represent 12 and 17 household units, respectively) are based on the low proportion of residential rooms or residential suites as determined by either domestic floor features such as hearths and grinding bins (Windes, 1984), or from the pattern of first-floor doorway connections (Bernardini, 1999). Windes (1984) estimates that at a minimum, 45 households were occupied during the over 200-year occupation of Pueblo Bonito. If we assume 5-6 residents per household (see Turner and Lofgren, 1966; Windes, 1984), Pueblo Bonito would have had a minimum total cumulative population of 225-270 people over its entire occupation.

Although this population estimate appears low in light of architectural remains indicating approximately 650 rooms at Pueblo Bonito, it is important to consider that the majority of these rooms likely served as storage. It is also important to consider that the estimate of 650 rooms represents a total over all construction periods (approximately 240 years). The number of available rooms at any one time was certainly less than 650 (for discussion, see Windes, 1984). Also, as is common at archaeological sites in the Southwest, there is evidence that rooms were periodically falling into disuse at the pueblo and were being used as middens and/or for burials (Akins, 1986), further reducing the number of available rooms at any give time.
Population health. Research examining the health of the two Pueblo Bonito populations has described the prevalence of nutrition-related pathological conditions including porotic hyperostosis and cribra orbitalia, as well as degenerative conditions such as osteoarthritis (Akins, 1986; El Najjar et al., 1976; Ortner and Putschar, 1981; Palkovich, 1984; Von Endt and Ortner, 1982). Although this research suggests significant infectious disease involvement for both Pueblo Bonito populations (Akins, 1986; Palkovich, 1984, p. 111), the disease profile for these populations is consistent with that described for other prehistoric Pueblo Indian communities (e.g. Palkovich, 1980).

The incidence of trauma and trauma-related death has also been described for Pueblo Bonito (Turner and Turner, 1999). Turner and Turner (1999) describe the incidence of trauma-related injuries and even cannibalism for primarily the west population of Pueblo Bonito (but see Bustard, 2000). It seems possible that inter- or intracommunity violence, or more likely regional conflict, was at least sporadic in Chacoan culture, probably the result of drought-related competition for resources in a marginal environment (but for an alternative explanation, see Hurlbut, 1999; Turner, 1993; Turner and Turner, 1999).

\section{Prehistoric Puebloan social organization}

Since initial attempts in the 1960s and 1970s to investigate social organization in the prehistoric Southwest using archaeological remains (e.g., Clemen, 1976; Ember, 1973; Hill, 1966, 1970; Longacre, 1964, 1966), this subject has received limited attention by researchers (but see Birkby, 1982; Howell and Kintigh, 1996; James, 1994; Peregrine, 2001). Hill $(1966,1970)$ investigated prehistoric postmarital residence at Broken $\mathrm{K}$ Pueblo in eastern Arizona ( $\mathrm{AD}$ 1200-1300), using a series of artifact classes and architectural features. Through analogy with the Hopi and Zuni Pueblo peoples, Hill $(1966,1970)$ concluded that the residents of Broken K Pueblo were likely matrilocal, with matrilineal descent.

Longacre $(1964,1968)$ investigated postmarital residence at the Carter Ranch site in eastern Arizona (AD 1100-1250), using ceramic design motifs. For these studies, Longacre $(1964,1968)$ recorded 175 different design elements in over 6,000 sherds, and found that specific elements clustered repeatedly in specific rooms within the pueblo. Assuming pottery production was a female activity, Longacre (1964, 1968) concluded that these clusters represented a lineal descent groups composed of related females and their husbands.

Recently, research examining domestic floor area, in conjunction with ethnographic analogy, concluded that the prehistoric pattern of postmarital residence at Chaco Canyon was likely matrilocal (Peregrine, 2001; Peregrine and Ember, 2002; but see Schillaci and Stojanowski, 2002). Based on previous research by Ember (1973), Peregrine (2001) 
concluded that the domestic floor area of Pueblo II period sites (AD 900-1100) in Chaco Canyon had increased to a level consistent with floor areas for matrilocal cultures recorded in the Human Relations Area File. Furthermore, the author argued that matrilocality among the presumed most likely descendents of the Chacoans (i.e., the Zuni and Hopi) suggests that the prehistoric pattern of residence for the Chacoans was likely female-based (Peregrine, 2001).

Although never formally tested, there is a longstanding hypothesis that Chacoan communities, as well as other prehistoric Pueblo Indian communities in the San Juan Basin of northwest New Mexico and southwestern Colorado, had developed a social structure based on exogamous matrilineal clans (Eggan, 1950; Steward, 1937) during the Pueblo II and Early Pueblo III periods (AD 900-1140). This unilineal clan-based system is often regarded as the ancestral "Anasazi" condition now seen among the present-day Western Pueblo Indians such as the Hopi and Zuni Indians, and in a modified state among some Eastern Pueblo Indians, including the Towa speakers of Jemez Pueblo and the eastern Keresan-speaking Pueblos in the Rio Grande Valley (for a description of Pueblo Indian linguistic classification, see Trager, 1967). The bilateral dual organization observed among the Rio Grande Tanoan Pueblos, including the Tewa- and Tiwa-speaking pueblos, is thought to have developed from this ancestral Anasazi condition subsequent to the abandonment of the San Juan Basin when populations migrated east to the Rio Grande region sometime during the twelfth century (Eggan, 1950). The unique pattern of social organization seen among the eastern Keresan pueblos is thought to have resulted from interaction with the bilateral organization of the Rio Grande Tanoan groups during the fourteenth century, when Keresan-speaking populations migrated into the Rio Grande area from the San Juan Basin to the west (Eggan, 1950; but see Eggan, 1972; Fox, 1972).

\section{Biological approaches to the study of postmarital residence}

Previous research on postmarital residence. As discussed earlier, archaeological studies of prehistoric postmarital residence initially investigated the intrasite distribution of presumed sex-specific artifact classes (Binford, 1962; Deetz, 1960, 1965, 1968; Hill, 1966; Longacre, 1964, 1966, 1968; McPherron, 1967; Whallon, 1968; Wright, 1966). Despite initial popularity, many of these archaeological studies were later criticized for being based on unsupported assumptions, and for failing to consider the depositional processes at the archaeological sites under study (Dumond, 1977; Lischka, 1975; Plog, 1978; Sebastian, 1992; Stanislawski, 1973). Allen and Richardson (1971) proposed that these studies utilized an overly simplistic view of residence, and that the ethnographic data suggest that postmarital residence is often far more complicated than adhering to a single residence rule. Furthermore, societal ideals regarding postmarital residence are only tangentially, at best, related to craft production (Allen and Richardson, 1971). Also, archaeological approaches must rely on the assumption that the division of labor is known without error and is strictly practiced. Moreover, unlike genetically determined biological traits, the lineal transmission of craft production techniques is not governed by any laws or principals that would ensure a predictable relationship between generations (Konigsberg, 1987).

Borrowing largely from the ideas of Deetz (1960, 1965), Lane and Sublett (1972) and Spence (1971, $1974 a, b)$ were the first to formally examine betweenand within-group patterns of biological variability to estimate postmarital residence (but see Hulse, 1941; Lewis and Lewis, 1961). These early models formed the basis for future studies using biological data (e.g., Birkby, 1982; Kennedy, 1981; Konigsberg, 1987, 1988; Konigsberg and Buikstra, 1995; Stefan, 1999). Konigsberg (1987) is credited with formalizing these models within a population genetics framework by partitioning the standardized genetic variance into female and male subcomponents. Using computer simulation, Konigsberg (1987) verified the implicit assumption that differential migration by males or females results in measurable differences in observed sex-specific, within-site genetic and phenotypic variability. Finally, Konigsberg $(1987,1988)$ further established that the homogenizing effects of multigenerational gene flow do not alter the variability expressed through differential postmarital residence practices (contra Kennedy, 1981; Neves, 1984).

Despite considerable theoretical and methodological improvement, the actual application of these techniques has been somewhat limited, particularly in the American Southwest. Three notable exceptions are studies by Corruccini (1972), Birkby (1982), and Howell and Kintigh (1996). Corruccini (1972) was the first to formally examine patterns of sex-specific variability in size and shape as a means for inferring postmarital residence at prehistoric Puebloan communities including Pueblo Bonito. In this study, Corruccini (1972, p. 383) found that "[b]oth size and shape show marked differential variability with respect to sex" and that "[i]ntrapopulational size distances are smaller, shape distances larger, and intrapopulational cohesiveness more complete, for females than for males." This pattern of greater female phenotypic cohesiveness was interpreted as being consistent with a pattern of matrilocal residence and exogamous matrilineal clan organization for the populations included in his study.

Birkby (1982) collected cranial nonmetric data for two distinct burial groups at Grasshopper Pueblo in eastern Arizona (ca. AD 1250-1450), and used these data to investigate sex-specific differences in biological distance. The pattern of distances indicated that 
the two separate burial groups were relatively distinct biologically and likely represented well-defined social units within the community. In addition, females exhibited greater within-group homogeneity, which was interpreted as evidence of a female-based residence system with male exogamy.

Howell and Kintigh (1996) utilized biological data to investigate social organization at the ancestral Zuni site of Hawikku in western New Mexico (ca. AD 1300-1670). Although postmarital residence was not discussed, the authors utilized sex and age distributions, as well as nonmetric trait frequencies, to investigate pattern differences in trait expression between the distinct burial regions at the site. All areas generally exhibited normal sex and age distributions, and the nonmetric trait distributions provided limited evidence for kin-oriented burial within each grouping. These data were then considered in light of variability in mortuary treatment to argue for ascribed "leader" status based on membership in chosen kin groups (but see Corruccini, 1998).

The biologically based research cited above demonstrates that sex-specific pattern differences in genetically determined phenotypic variance can be used effectively to estimate postmarital residence patterns in prehistoric communities. Using biological data, rather than material culture or architectural data, is perhaps more appropriate for investigating postmarital residence in prehistoric societies, because the lineal transmission of craft production techniques is not governed by any laws or principles that necessarily result in predictable relationships between generations. The transmission of biological variability, on the other hand, is governed by principles of genetic inheritance and trait heritability (Hartl and Clark, 1989). Both metric and nonmetric traits of the craniofacial skeleton have been demonstrated to be moderately heritable, and thus useful for genetic distance studies, or as in this case, studies of between- and within-group genetic variance (see Cheverud, 1988; Cheverud et al., 1979; Corruccini, 1976; Corruccini et al., 1982; Konigsberg and Ousley, 1995; Sjøvold, 1984; Susanne 1977).

\section{HYPOTHESIS}

Previous research relying largely on ethnographic analogy (e.g., Eggan, 1950) asserted that the Western Anasazi in general, and Chacoan culture in particular (Peregrine, 2001), likely conformed to a pattern of social organization structured around female-based descent and postmarital residence. This assertion is supported by the results presented by Corruccini (1972) of his analysis of biological variation at a number of prehistoric pueblos, including Pueblo Bonito. Based on this previous research, we examine the hypothesis that the residents of Pueblo Bonito conformed to a socially prescribed pattern of female-based postmarital residence (matrilocality). Under this hypothesis, the expected pattern of sexspecific phenotypic variation associated with femalebased residence at Pueblo Bonito would include greater within-group male variation, and greater between-group female variation.

\section{Theoretical and methodological assumptions}

As with any scientific model, the use of sex-specific pattern differences in phenotypic variance to estimate postmarital residence, or any other aspect of social organization, relies on theoretical assumptions. The assumptions used here were derived from previous research presented in the anthropological literature (i.e., Lane and Sublett, 1972; Spence, 1974a, b; Konigsberg, 1987, 1988). Our analyses rely primarily on two theoretical assumptions:

1. For within-group analyses, the sex with the greater variability is the more mobile sex. For example, a situation of greater male variability is consistent with the in-migration of largely unrelated males coincident with a matrilocal residence pattern, assuming nonprescribed group exogamy. The nonmobile sex is theoretically composed of related individuals that tend to exhibit similar phenotypic variance and covariance for all genetically determined traits due to common descent.

2. For between-group analyses, the sex with the greater between-group variability represents the nonmobile sex. The nonmobile sex would not experience the homogenizing effects of gene flow and will tend to exhibit a greater degree of between-group variance and genetic divergence (e.g., Agiuar and Neves, 1991).

Our analyses also rely on three methodological assumptions:

1. The sex of each individual in our analyses was estimated without error.

2. The skeletal series from Pueblo Bonito represent two largely contemporaneous populations.

3 . The individuals buried within the two burial clusters were members of the population those clusters represent. In other words, the burials recovered from Pueblo Bonito were of the inhabitants of that pueblo. This assumption is equivalent to the assumption of association central to modern archaeological method and theory. As is true for any epistemological argument, we cannot say with certainty that the burials excavated at Pueblo Bonito are of individuals who lived, reproduced, and died at Pueblo Bonito, just as we cannot say with certainty that the material and architectural remains found at Pueblo Bonito were produced and/or used by the residents of this pueblo. However unlikely, it is possible that the deceased were brought from other communities to Pueblo Bonito for burial. Because there is good evidence of a resident population at this pueblo, and because there is, to our knowledge, no ethnohistorical record documenting a Puebloan practice of burying residents of one pueblo within 
the walls of another pueblo, we feel that it is not unreasonable to assume that these burials represent the once-living residents of Pueblo Bonito.

\section{MATERIALS AND METHODS Population samples}

The samples used for our analyses of postmarital residence and biological variation at Pueblo Bonito were excavated from two discrete burial clusters (Fig. 2). The first cluster, excavated by George Pepper, is derived from rooms $32,33,53$, and 56 in the northern portion of the pueblo (North population, $\mathrm{n}=12$ ); the second cluster, excavated by Neil Judd, is derived from rooms $320,326,329$, and 330 from the western portion of the pueblo (West population, $\mathrm{n}=15$ ). The North population is comprised of 7 males and 5 females, while the West population has 5 males and 10 females. Although there is evidence suggesting these samples represent largely contemporaneous yet distinct biological units (Akins, 1986; Schillaci et al., 2001), we cannot be certain of this. We therefore examined sex-specific pattern differences in phenotypic variance for each of the two Pueblo Bonito populations independently, as well as for the two populations pooled $(\mathrm{n}=27)$.

\section{Data collection}

The biological data used in this analysis consist of nine craniofacial variables. Measurements were taken to the nearest $0.10 \mathrm{~mm}$, using Mitutoyo digital calipers. All measurements were taken by one of the authors (M.A.S.), using the same set of digital calipers over a 5-day period.

The sex of each individual was estimated with the methods described in Buikstra and Ubelaker (1994), using the secondary sexual characteristics of the os coxa and cranium. When possible, both the os coxa and cranium were evaluated. When the sex estimate based on cranial characteristics was not in agreement with the estimate based on pelvic morphology, the estimate based on the pelvis was used. Because one of our major methodological assumptions is that the sex of each individual is estimated without error, we compared our sex estimates with those published elsewhere for the same samples (i.e., Akins, 1986; Hrdlička, 1931) to determine if this assumption was reasonably satisfied.

\section{Univariate data analysis}

For each craniometric variable, the between-sex difference in within-group variance was tested using a univariate F-test. The F-test was chosen for this study because it is considered by many the standard method for comparing variation in a single variable in two samples (see Manly, 1994, p. 44), and because the results are relatively easy to interpret. The assumption of normality associated with the F-test was tested with the Wilk-Shapiro method, using the Univariate Procedure in SAS (1989). Because sample sizes are small, we bootstrapped the sample standard deviations to obtain bias-free estimates of variance (Efron, 1981). The between-sex, within-group differences in variance for all biascorrected variables were evaluated using an $\mathrm{F}$-test with $n_{1}-1$ and $n_{2}-1$ degrees of freedom.

\section{Multivariate data analysis}

Because we are interested in evaluating phenotypic variance across multiple variables, we also employed multivariate variance analyses. Multivariate analyses are considered superior to univariate analyses because the former take into consideration second-order interaction effects between variables, which may be more important than single effects considered in isolation (Howells, 1969; Rightmire, 1970; but see Kowalski, 1972).

To estimate multivariate variance differences, we used determinant ratio analysis (cf. Konigsberg, 1988; Raemsch, 1995; Stefan, 1999). The determinant is a scalar quantity that serves as a measure of variability within a sample variance-covariance matrix (Green, 1976). We utilized the RANDET2 randomization program for our determinant computations (for a description, see Konigsberg, 1988, p. 478) that calculates the determinant of the variance-covariance matrix $|\mathrm{C}|$ for each group (i.e., male and female). The program then calculates the natural logarithm of the ratio of the male to female determinants: $\ln (\mid \mathrm{C}$ o $|/| \mathrm{C} q \mid)$. The natural $\log$ of the ratio of male-to-female determinants is expected to be zero when equal mobility between the sexes exists (Konigsberg, 1988). When males are more mobile (a pattern consistent with matrilocal residence), the natural log of the determinant ratio is positive. Conversely, when this value is negative, greater female mobility is indicated, a pattern consistent with a male-based residence pattern such as patrilocal or avunculocal residence. To assess statistical significance, the data are resampled (500 iterations) after random shuffling to create a randomization distribution of determinant ratio values. The $P$-value is provided by the proportion of resampled values greater than or equal to the observed determinant ratio.

To avoid generating singular variance-covariance matrices, sample variance-covariance matrices were generated using $n-1$ variables where $n$ is the sample size of the smallest group $(n=5)$. Variable reduction was achieved using stepwise discriminant analysis of the craniometric data. Stepwise discriminant analysis identified four variables significant $(\alpha=0.05)$ for discriminating between sex-specific groupings (see Tables 1 and 2).

In addition to the determinant ratio analysis, we also generated minimum genetic distances between sex-specific groupings, using the same four variables identified by stepwise discriminant analysis. The more mobile sex was expected to exhibit a closer between-group minimum genetic distance due to inmigration from common source populations, while the nonmobile sex was expected to exhibit greater 
TABLE 1. Univariate variance tests for North population of Pueblo Bonito ${ }^{1}$

\begin{tabular}{|c|c|c|c|c|c|c|c|}
\hline \multirow[b]{2}{*}{ Variable } & \multicolumn{3}{|c|}{ Males $(\mathrm{n}=7)$} & \multicolumn{3}{|c|}{ Females $(\mathrm{n}=5)$} & \multirow[b]{2}{*}{$F^{2}$} \\
\hline & SD & Boot & Bias & SD & Boot & Bias & \\
\hline 1) Upper facial height & 4.24 & 4.02 & +0.22 & 4.39 & 4.15 & +0.24 & 1.07 \\
\hline 2) Left orbital height & 1.68 & 1.53 & +0.15 & 2.36 & 2.13 & +0.23 & 1.94 \\
\hline 3) Left orbital breadth & 2.15 & 1.83 & +0.32 & 1.98 & 1.89 & +0.09 & 1.07 \\
\hline 4) Nasal height & 1.25 & 1.25 & 0.00 & 2.07 & 1.94 & +0.13 & 2.41 \\
\hline 5) Nasal breadth & 2.93 & 3.05 & -0.12 & 2.10 & 1.91 & +0.19 & 2.55 \\
\hline 6) Internal palatal breadth & 1.53 & 1.27 & +0.26 & 0.95 & 0.89 & +0.06 & 2.04 \\
\hline 7) Internal palatal length & 1.08 & 0.90 & +0.18 & 1.17 & 1.04 & +0.13 & 1.34 \\
\hline 8) Interorbital breadth & 2.73 & 2.58 & +0.15 & 1.39 & 1.16 & +0.23 & 4.95 \\
\hline 9) Upper facial breadth & 3.50 & 3.18 & +0.32 & 3.68 & 3.28 & +0.40 & 1.06 \\
\hline
\end{tabular}

${ }^{1}$ Variables 1-8 were recorded in accordance with the protocol outlined in Bass (1995). Variable 9 was recorded in accordance with the protocol defined by Martin and Saller (1957), as described in White and Folkens (2000). Variables 1, 3, 7, and 9 were identified as significant $(\alpha=0.05)$ for discriminating between sex-specific groupings, using stepwise discriminant analysis. The assumption that variables were normally distributed for both sexes was examined using a Wilk-Shapiro test $(\alpha=0.05)$. The distribution of values for variable 5 (Nasal height) deviated significantly from normality for both males $(P=0.038)$ and females $(P=0.046)$. The greater standard deviation is identified in bold. SD, standard deviation; Boot, bootstrapped standard deviation; Bias, estimated bias for uncorrected standard deviation. ${ }^{2} \mathrm{~F}_{(0.05,6,4)}=6.16 ; \mathrm{F}_{(0.05,4,6)}=4.53$.

TABLE 2. Univariate variance tests for West population of Pueblo Bonito ${ }^{1}$

\begin{tabular}{|c|c|c|c|c|c|c|c|}
\hline \multirow[b]{2}{*}{ Variable } & \multicolumn{3}{|c|}{ Males $(\mathrm{n}=5)$} & \multicolumn{3}{|c|}{ Females $(\mathrm{n}=10)$} & \multirow[b]{2}{*}{$F^{2}$} \\
\hline & SD & Boot & Bias & $\mathrm{SD}$ & Boot & Bias & \\
\hline 1) Upper facial height & 4.58 & 3.81 & +0.77 & 3.87 & 3.94 & -0.07 & 1.07 \\
\hline 2) Left orbital height & 2.29 & 1.97 & +0.32 & 1.76 & 1.62 & +0.14 & 1.48 \\
\hline 3) Left orbital breadth & 1.37 & 1.24 & +0.13 & 2.55 & 2.35 & -0.20 & 3.59 \\
\hline 4) Nasal height & 0.66 & 0.62 & +0.04 & 1.44 & 1.35 & +0.09 & 4.74 \\
\hline 5) Nasal breadth & 2.60 & 1.31 & +1.29 & 2.75 & 2.35 & +0.40 & 3.22 \\
\hline 6) Internal palatal breadth & 1.38 & 1.14 & +0.24 & 1.20 & 1.06 & +0.14 & 1.16 \\
\hline 7) Internal palatal length & 1.95 & 1.82 & +0.13 & 1.29 & 1.19 & +0.10 & 2.34 \\
\hline 8) Interorbital breadth & 2.02 & 1.95 & +0.07 & 2.56 & 2.52 & +0.04 & 1.67 \\
\hline 9) Upper facial breadth & 3.30 & 2.95 & +0.35 & 3.65 & 3.22 & +0.43 & 1.19 \\
\hline
\end{tabular}

${ }^{1}$ Measurement variables 1-8 were taken in accordance with the protocol outlined in Bass (1995). Variable 9 was recorded in accordance with the protocol defined by Martin and Saller (1957), as described in White and Folkens (2000). Variables 1, 3, 7, and 9 were identified as significant $(\alpha=0.05$ ) for discriminating between sex-specific groupings, using stepwise discriminant analysis. The assumption that variables were normally distributed for both sexes was examined using a Wilk-Shapiro test $(\alpha=0.05)$. All variables were normally distributed for both males and females. The greater standard deviation is identified in bold. SD, standard deviation; Boot, bootstrapped standard deviation; Bias, estimated bias for uncorrected standard deviation. ${ }^{2} \mathrm{~F}_{(0.05,4,9)}=3.63 ; \mathrm{F}_{(0.05,9,4)}=6.0$.

between-group distances due to the lack of betweengroup migration. Bias-corrected minimum genetic distances among sex-specific groups were generated from the minimum genetic relationship (R) matrix (see Relethford and Blangero, 1990; Relethford et al., 1997; Williams-Blangero and Blangero, 1989) using RMET 4.0, a quantitative genetics software package made available by Dr. J. Relethford (http:// konig.la.utk.edu/relethsoft.html, accessed on May 1, 2002). Minimum genetic relationships were presented graphically, using principal coordinate ordination of the scaled eigenvectors from the $R$ matrix (for a detailed description of calculations, see Relethford et al., 1997).

\section{RESULTS \\ Assumptions}

A comparison of our estimates of sex with those made by Akins (1986) and Hrdlička (1931), using the secondary sexual characteristics of the cranium and os coxa, indicates that our explicit assumption regarding correct sex estimation is likely reasonable. Our estimates differed from those made by Hrdlička (1931) for 2 of 8 comparisons (25\%). Complete agree- ment, however, was observed between our estimates and those presented by Akins (1986).

\section{Univariate tests}

The bootstrapped estimates of the within-group standard deviations and F-test $P$-values for the West population within-group, between-sex comparisons are presented in Table 1. Although females exhibit larger standard deviations for 6 of 9 variables, none of these differences is statistically significant at the $\alpha=0.05$ level. While the results of the univariate variance tests are largely uninformative, the general trend of greater female variance is indicated by larger bias-adjusted standard deviations for a majority of variables. These results are contrary to the expected matrilocal pattern of greater male variance.

Results from the North population within-group, between-sex comparisons are presented in Table 2 . Greater female variance is again indicated by larger standard deviations for 6 of 9 variables, with none of these comparisons significant at the $\alpha=0.05$ level. These results also support a conclusion of increased 
TABLE 3. Univariate variance tests for pooled Pueblo Bonito sample ${ }^{1}$

\begin{tabular}{|c|c|c|c|c|c|c|c|}
\hline \multirow[b]{2}{*}{ Variable } & \multicolumn{3}{|c|}{ Males $(\mathrm{n}=12)$} & \multicolumn{3}{|c|}{ Females $(\mathrm{n}=15)$} & \multirow[b]{2}{*}{$F^{2}$} \\
\hline & $\mathrm{SD}$ & Boot & Bias & $\mathrm{SD}$ & Boot & Bias & \\
\hline Upper facial height & 4.80 & 4.72 & +0.08 & 4.53 & 4.93 & -0.40 & 1.09 \\
\hline Left orbital height & 1.86 & 1.68 & +0.18 & 2.07 & 2.03 & +0.04 & 1.46 \\
\hline Left orbital breadth & 2.25 & 1.92 & +0.33 & 2.46 & 2.21 & +0.25 & 1.33 \\
\hline Nasal height & 1.54 & 1.42 & +0.12 & 1.60 & 1.64 & -0.04 & 1.33 \\
\hline Nasal breadth & 3.05 & 3.09 & -0.04 & 2.68 & 2.68 & 0.00 & 1.33 \\
\hline Internal palatal breadth & 1.47 & 1.35 & +0.12 & 1.15 & 1.33 & -0.18 & 1.03 \\
\hline Internal palatal length & 1.45 & 1.46 & -0.01 & 1.75 & 1.72 & +0.03 & 1.39 \\
\hline Interorbital breadth & 2.48 & 2.31 & +0.17 & 2.19 & 2.11 & +0.08 & 1.20 \\
\hline Upper facial breadth & 4.55 & 4.04 & +0.51 & 3.91 & 4.22 & -0.31 & 1.09 \\
\hline
\end{tabular}

${ }^{1}$ Variables 1-8 were recorded in accordance with the protocol outlined in Bass (1995). Variable 9 was recorded in accordance with the protocol defined by Martin and Saller (1957), as described in White and Folkens (2000). The assumption that variables were normally distributed for both sexes was examined using a Wilk-Shapiro test $(\alpha=0.05)$. None of the variables deviated significantly from normality. The greater standard deviation is identified in bold. SD, standard deviation; Boot, bootstrapped standard deviation; Bias, estimated bias for uncorrected standard deviation. ${ }^{2} \mathrm{~F}_{(0.05,11,14)}=2.57 ; \mathrm{F}_{(0.05,14,11)}=2.72$.

TABLE 4. Natural log of determinant ratios and randomization $\mathrm{P}$-values

\begin{tabular}{lccc}
\hline Population & $\ln (\mid \mathrm{C}$ ๙ $|/ \mathrm{C} \uparrow|)$ & $\begin{array}{c}\text { Greater } \\
\text { variability }\end{array}$ & $\begin{array}{c}\text { Randomization } \\
P \text {-value }\end{array}$ \\
\hline West & -3.30 & Female & 0.229 \\
North & -6.59 & Female & 0.128 \\
Pooled & -1.52 & Female & 0.208 \\
\hline
\end{tabular}

female variability, which is contrary to expectations of a matrilocal residence pattern.

Although there is biological evidence suggesting that the North and West populations represent distinct biological populations (Akins, 1986; Schillaci et al., 2001), this interpretation might not be universally accepted among researchers focusing on material culture and architectural data. We therefore conducted a formal comparison of male and female variability, using the pooled Pueblo Bonito sample $(\mathrm{n}=27)$. The results of these F-tests are presented in Table 3. Although none of the between-sex comparisons of phenotypic variability were statistically significant, the general pattern of increased female variability encountered with the individual sample analyses is also apparent for the pooled sample analysis, with females more variable for 6 of 9 variables. This finding does not support the hypothesis of matrilocality for the populations buried at Pueblo Bonito.

\section{Multivariate tests}

We performed three within-group, between-sex determinant ratio analyses to evaluate our hypothesis of matrilocality at Pueblo Bonito. The first of these was a between-sex test for the West sample, the second a between-sex test for the North population, and the third a between-sex test for the pooled sample. As indicated in Table 4, females exhibit higher within-group variation for each population independently, as well as for the pooled sample. None of these ratios, however, was significant at the $\alpha=0.05$ level. As a whole, the results of the determinant ratio analysis correspond nicely with the univariate results, suggesting that the Chacoan pop-
TABLE 5. Bias-corrected minimum genetic distances derived from minimum $R$ matrix, using equal population weights and a narrow-sense heritability of $0.55^{1}$

\begin{tabular}{|c|c|c|c|c|}
\hline & North ô & North 9 & West ô & West $q$ \\
\hline North $\sigma^{\top}$ & 0.0000 & 0.4325 & 0.3589 & 0.2915 \\
\hline North 9 & 1.6948 & 0.0000 & 0.3879 & 0.2541 \\
\hline West 0 & 1.1136 & 1.0864 & 0.0000 & 0.1368 \\
\hline West $q$ & 1.0755 & 0.6151 & 0.0634 & 0.0000 \\
\hline
\end{tabular}

${ }^{1}$ Distances among sex-specific groupings are listed below the diagonal. Standard errors are listed above the diagonal.

ulation(s) buried at Pueblo Bonito likely did not develop a social system centered on female-based postmarital residence.

The unbiased minimum genetic distances are presented in Table 5. The closest relationship was observed between the West population males and females, while the most distant relationship was observed between the North sample males and females. Males exhibited a greater within-sex, between-population minimum genetic distance $\left(\mathrm{d}^{2}=\right.$ $1.113)$ than did females $\left(\mathrm{d}^{2}=0.615\right)$. This pattern of greater male within-sex, between-population distance is incongruous with the prediction of greater between-group male homogeneity due to in-migration from common sources (i.e., matrilocality). The comparatively close minimum genetic relationship between the West population males and females, combined with the comparatively distant relationships between populations, suggests some degree of endogamy for the West population (see Fig. 3).

\section{DISCUSSION}

The results of the univariate analyses of betweensex differences in within-group phenotypic variance do not support the hypothesis based on previous research (i.e., Corruccini, 1972; Eggan, 1950; Peregrine, 2001) that the occupants of Pueblo Bonito prescribed to a system of social organization centered on matrilocal residence. Likewise, the pooled sample tests do not conform to the expected pattern of lower female within-group variability indicative of female-based postmarital residence. 


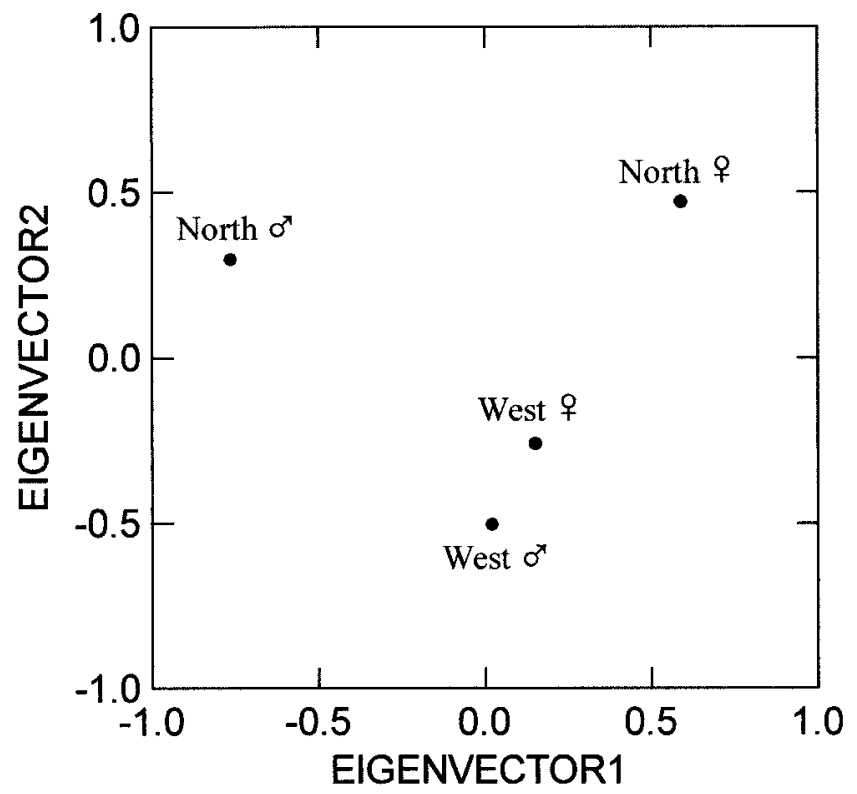

Fig. 3. Principal coordinate ordination of the first two eigenvectors of the estimated minimum genetic relationship $(\mathrm{R})$ matrix comprising $57.5 \%$ and $38.1 \%$ of the variation. The $\mathrm{R}$ matrix was generated using equal population weights and a narrow-sense heritability of 0.55 . Each eigenvector is scaled by the square root of its corresponding eigenvalue.

The multivariate determinant ratio analyses seem to support the univariate results suggesting that the residents of Pueblo Bonito were likely not matrilocal. The results indicate greater female variability for both the North and West populations. These findings are contrary to the expected pattern of greater male variability consistent with matrilocal postmarital residence. Furthermore, males exhibit a greater within-sex minimum genetic distance than that observed for females, indicating genetic isolation between male populations, possibly due to a bilocal/patrilocal residence pattern. The pattern we present is more consistent with a male-based patrilocal residence preference than with the hypothesized matrilocal pattern of greater male variance. A primarily bilocal pattern of residence, possibly with a slight preference for patrilocality, is perhaps the most reasonable estimate of postmarital residence at Pueblo Bonito, considering the lack of statistically significant findings. This pattern is most consistent with the bilocal residence associated with dual organization, such as the nonexogamous moietal system seen among many present-day Eastern Pueblo Indian populations, including the Tewa speakers of the northern Rio Grande Valley (see Ortiz, 1969).

The results of this analysis are significant because they seem to suggest that the bilocal dual organization seen among the Eastern Pueblo Indians was present in Chacoan culture prior to the presumed eastern migration by San Juan populations sometime after $\mathrm{AD} 1100$, a hypothesis first presented by Vivian (1970; for discussions, see Altschul, 1978;
Eggan, 1950, 1972; Fox, 1972; Grebinger, 1973). Furthermore, the preference for such a system of social organization in a large regional center such as Pueblo Bonito brings into question the idea that the clan-based matrilineal/matrilocal system seen among the present-day Western Pueblos was the ancestral Anasazi condition (contra Eggan, 1950).

\section{Limitations to the study}

The results of our analysis are subject to several important limitations. The lack of significant comparisons for our univariate and multivariate tests has several possible explanations, the first of which is that no significant differences truly exist. If there were no strict social rules governing postmarital residence in either of the two populations at Pueblo Bonito, we would not expect strong patterns in sexspecific phenotypic variance. A second explanation for the general lack of statistical significance is the small sample sizes used in our study. With small sample sizes, the probability of detecting a significant difference when one exists decreases. Although details of the power computations are beyond the focus of this paper, the calculated probability of accepting a true null hypothesis in this study was only 0.50 (following the operating characteristic curves in Montgomery (1991) and assuming an alpha level of 0.05 with a meaningful difference in variance estimated as 1 unit). In other words, because of small sample sizes, there was only a 50\% chance of detecting a significant difference when one truly exists. Given this, it is not surprising that we did not find any significant differences between male and female variances. However, despite the nonsignificant results, a general pattern of decreased within-group male variance associated with an increased withingroup female variance is evident. This general pattern runs counter to the long-held hypothesis based on archaeological and ethnographic research that the residents of Chaco Canyon were likely matrilocal.

There are potential alternative explanations for the observed sex-specific pattern in phenotypic variance. Konigsberg $(1987,1988)$ found that both the number of migrants and the distance of migration affected the observed phenotypic genetic variance. For example, if the populations of Pueblo Bonito were primarily matrilocal but with a few females migrating in from greater distances than the average male migrant, then the observed female intracemetery variation might exceed observed male variances. Based on our assumptions (see above), this greater female phenotypic variance would be incorrectly interpreted as evidence for a male-based system of postmarital residence. One way to account for this potential problem would be to consider mate exchange within the entire social network. It is also important to consider that previous research of extant groups demonstrated that kin- and clan-structured migration can affect the observed genetic variability within and between groups (Fix, 1975, 1978, 
1984, 1993; Rogers, 1987; Williams-Blangero, 1987, 1989; Williams-Blangero and Blangero, 1989).

\section{CONCLUSIONS}

Several conclusions can be drawn from the results of our biological analysis of postmarital residence at Pueblo Bonito. Our original hypothesis, based on biological, ethnographic, and archaeological research (i.e., Corruccini, 1972; Eggan, 1950; Peregrine, 2001), that the inhabitants of Chaco Canyon, including Pueblo Bonito, conformed to a socially prescribed pattern of matrilocal postmarital residence was not supported by the results of our analyses. Pueblo Bonito society was more likely bilocal, with perhaps a slight preference for a male-based patrilocal or avunculocal residence. This pattern is consistent with the nonexogamous moieties, or dual organization, observed among many of the presentday Eastern Pueblos (for discussions, see Ortiz, 1969; Ware, 2001; Ware and Blinman, 2000). If the estimated pattern of bilocal residence at Pueblo Bonito was associated with a social structure based on dual organization, then the present-day Eastern Pueblo pattern of dual organization might have originated in the San Juan Basin (west) during the tenth or eleventh century, rather than in the Rio Grande region (east) sometime during the twelfth century, as suggested by previous researchers (e.g., Eggan, 1950).

We temper these conclusions, however, with the realization that we have only a small glimpse of within-site variability in this regional system. This glimpse is derived from only one site, Pueblo Bonito, which might or might not be representative of Chacoan social organization as a whole. Unfortunately, the Pueblo Bonito skeletal sample is the largest among Chacoan sites, thus precluding similar analyses using other samples from this regionally important culture. It is also important to note that the diversity and complexity of prehistoric Puebloan social organization in the San Juan Basin were likely great, and that evidence for patrilocal residence at one regional center does not represent evidence for a region-wide pattern of postmarital residence. Continued research incorporating ethnographic, archaeological, and biological perspectives is needed before we can begin to characterize the regionally diverse social organization of the prehistoric Pueblo world.

\section{ACKNOWLEDGMENTS}

We are especially grateful to T. Windes of the National Park Service for facilitating this research and for his interest and encouragement in applying biological data to investigate archaeological questions. We are indebted to L. Konigsberg and C. Raemsch for providing the computer program used for generating determinant ratios, and to J. Relethford for his guidance in using RMET 4.0. We thank D. Hunt (United States National Museum of Natural History) and K. Mowbray (American Museum of
Natural History) for providing access to the Southwest skeletal collections curated at their respective institutions. We also thank J. Ware, J. Mathien, W. Bustard, W. Wills, L. Konigsberg, J. Kantner, T. Howell, T. McIlwraith, and three anonymous reviewers for their valuable comments and criticisms of earlier drafts. We thank C. Schillaci for providing editorial assistance. R. Stauber and T. Windes provided the maps included here. Special thanks go to L. Stutz, J. Stutz, and L. Hecker for their support of this project. Although this research benefited greatly from their help, responsibility for any and all interpretations, errors, or omissions lies solely with the authors. Much of the research described here was presented at the 69th annual meeting of the American Association of Physical Anthropologists in San Antonio, Texas (see Schillaci and Stojanowski, 2000).

\section{LITERATURE CITED}

Aguiar GFS, Neves W. 1991. Postmarital residence and withinsex genetic diversity among the Urubu-Ka'apor Indians, Brazilian Amazon. Hum Biol 63:467-488.

Akins NJ. 1986. A biocultural approach to human burials from Chaco Canyon, New Mexico. Reports of the Chaco Center no. 9. Santa Fe: Branch of Cultural Research, National Park Service.

Akins NJ, Schelberg JD. 1984. Evidence for organizational complexity as seen from the mortuary practices at Chaco Canyon. In: Judge WG, Schelberg JD, editors. Recent research on Chaco prehistory. Reports of the Chaco Center no. 8. Albuquerque: Division of Cultural Research, National Park Service. p 89102.

Allen WL, Richardson JB III. 1971. The reconstruction of kinship from archaeological data: the concepts, the methods, and the feasibility. Am Antiq 36:41-53.

Altschul JH. 1978. The development of the Chacoan interaction sphere. J Anthropol Res 34:109-146.

Bass WM. 1995. Human osteology, a laboratory and field manual, 4th ed. Columbia, MO: Missouri Archaeological Society.

Bernardini W. 1999. Reassessing the scale of social action at Pueblo Bonito, Chaco Canyon, New Mexico. Kiva 64:447-470.

Binford LR. 1962. Archaeological investigations in the Carlyle Reservoir, Clinton County, Illinois, 1962. Archaeological salvage report no. 17. Carbondale: Southern Illinois University Museum.

Birkby WH. 1982. Biosocial interpretations from cranial nonmetric traits of Grasshopper Pueblo skeletal remains. In: Longacre WA, Holbrook SJ, Graves MW, editors. Multidisciplinary research at Grasshopper Pueblo, Arizona. Anthropological papers of the University of Arizona no. 40. Tucson: University of Arizona Press. p 36-41.

Buikstra JE, Ubelaker DH. 1994. Standards for data collection from human skeletal remains. Arkansas Archaeological Survey research series no. 44. Fayetteville: Arkansas Archaeological Survey.

Bustard W. 1999. Space, evolution, and function in the houses of Chaco Canyon. Environ Plann B Plann Design 26:219-240.

Bustard W. 2000. Chaco at the new millennium: nasty and brutish? Paper presented at the 65th annual meeting of the Society for American Archaeology. April 9, 2000, Philadelphia, PA.

Cheverud JM. 1988. A comparison of genetic and phenotypic correlations. Evolution 42:958-968.

Cheverud JM, Buikstra JE, Twitchell E. 1979. Relationships between non-metric skeletal traits and cranial size and shape. Am J Phys Anthropol 50:191-198.

Clemen RT. 1976. Aspects of prehistoric social organization on Black Mesa. In: Gamesman GJ, Eller RC, editors. Papers on the archaeology of Black Mesa, Arizona. Carbondale: Southern Illinois University Press. p 113-135. 
Corruccini RS. 1972. The biological relationships of some prehistoric and historic pueblo populations. Am J Phys Anthropol $37: 373-388$

Corruccini RS. 1976. The interaction between nonmetric and metric cranial variation. Am J Phys Anthropol 44:285-294.

Corruccini RS. 1998. On Hawikku cemetery kin groups. Am Antiq 63:161-163.

Corruccini RS, Handler JS, Mutaw RJ, Lange FW. 1982. Osteology of a slave burial population from Barbados, West Indies. Am J Phys Anthropol 59:443-459.

Deetz J. 1960. An archaeological approach to kinship change in eighteenth-century Arikara culture. Unpublished Ph.D. dissertation, Department of Anthropology, Harvard University.

Deetz J. 1965. The dynamics of stylistic change in Arikara ceramics. Illinois studies in anthropology no.4. Urbana: Illinois University Press.

Deetz J. 1968. The inference of residence and descent rules from archaeological data. In: Binford S, Binford L, editors. New perspectives in archaeology. Chicago: Aldine. p 41-48.

Drager DL. 1976. Anasazi population estimates with the aid of data derived from photogrammetric maps. In: Lyons TR, editor. Remote sensing experiments in cultural resource studies. Reports of the Chaco Center no. 1. Albuquerque: Division of Cultural Research, National Park Service. p 151-171.

Dumond DE. 1977. Science in archaeology: the saints go marching in. Am Antiq 42:330-349.

Efron B. 1981. Censored data and the bootstrap. J Am Stat Assoc 76:312.

Eggan F. 1950. Social organization of the western Pueblos. Chicago: University of Chicago Press.

Eggan F. 1972. Summary. In: Ortiz A, editor. New perspectives on the Pueblos. Albuquerque: University of New Mexico Press. p 287-305.

El-Najjar MY. 1978. Southwestern physical anthropology: do the cultural and biological parameters correspond? Am J Phys Anthropol 48:151-158.

El-Najjar MY, Ryan DJ, Turner CG II, Lozoff B. 1976. The etiology of porotic hyperostosis among the prehistoric and historic Anasazi Indians of the southwestern United States. Am J Phys Anthropol 44:477-488.

Ember M. 1973. An archaeological indicator of matrilocal versus patrilocal residence. Am Antiq 38:177-182.

Fix AG. 1975. Fission-fusion and lineal effect: aspects of the population structure of the Semai Senoi of Malaysia. Am J Phys Anthropol 43:295-302.

Fix AG. 1978. The role of kin-structured migration in genetic microdifferentiation. Ann Hum Genet 41:329-339.

Fix AG. 1984. Kin groups and trait groups: population structure and epidemic disease selection. Am J Phys Anthropol 65:201212.

Fix AG. 1993. Kin-structured migration and isolation by distance. Hum Biol 65:193-210.

Fox RJ. 1972. Some unsolved problems of Pueblo social organization. In: Ortiz A, editor. New perspectives on the Pueblos. Santa Fe: School of American Research. p 71-85.

Frisbie TR. 1978. High status burials in the American Southwest: an interpretive study. In: Riley CL, Hendrick BC, editors. Across the Chichimec Sea: papers in honor of J. Charles Kelley. Carbondale: Southern Illinois University Press. p 202-227.

Frisbie TR. 1980. Social ranking in Chaco Canyon, New Mexico. A Mesoamerican reconstruction. Trans Il State Acad Sci 72:6069.

Grebinger P. 1973. Prehistoric social organization in Chaco Canyon, New Mexico: an alternative reconstruction. Kiva 39:3-23.

Green PE. 1976. Mathematical tools for applied multivariate analysis. New York: Academic Press.

Hartl DL, Clark AG. 1989. Principles of population genetics. Sunderland: Sinauer Associates, Inc.

Hayes AC. 1981. A survey of Chaco Canyon archaeology. In: Brugge DM, Hayes AC, Judge WJ, editors. Archaeological surveys of Chaco Canyon, New Mexico. National Park Service archaeological series no. 17A, Chaco Canyon studies. Washington, DC: National Park Service. p 1-68.
Hill JN. 1966. A prehistoric community in eastern Arizona. Southwest J Anthropol 22:9-30.

Hill JN. 1970. Broken K Pueblo: prehistoric social organization in the American Southwest. Tucson: University of Arizona Press.

Howell TL, Kintigh KW. 1996. Archaeological identification of kin groups using mortuary and biological data: an example from the American Southwest. Am Antiq 61:537-554.

Howells WW. 1969. The use of multivariate techniques in the study of skeletal populations. Am J Phys Anthropol 31:311314.

Hrdlička, A. 1931. Catalogue of human crania in the United States National Museum collections. US Nat Mus Proc 78:1-95.

Hulse FS. 1941. The people who lived at Irene. In: Caldwell J, McCann C, editors. Irene Mound Group, Chatham County, Georgia. Athens: University of Georgia Press. p 57-68.

Hurlbut SA. 1999. Cannibals in the canyon? Taphonomic analysis of human remains from Chaco Canyon, New Mexico. Unpublished Ph.D. dissertation. Department of Anthropology, Arizona State University, Tempe.

James SR. 1994. Regional variation in prehistoric Pueblo households and social organization: a quantitative approach. Unpublished Ph.D. dissertation, Department of Anthropology, Arizona State University, Tempe.

Judd NM. 1925. Archaeological investigations at Pueblo Bonito, New Mexico. Smithsonian miscellaneous collections, volume 77. Washington, DC: Smithsonian Institution Press. p 83-91.

Judd NM. 1954. The material culture of Pueblo Bonito. Smithsonian miscellaneous collections, volume 124. Washington, DC: Smithsonian Institution Press.

Kelley JC, Kelley EA. 1975. An alternative hypothesis for the explanation of Anasazi culture history. In: Frisbie TR, editor. Collected papers in honor of Florence Hawley Ellis. Papers of the Archaeological Society of New Mexico, no. 2. Albuquerque: Archaeological Society of New Mexico. p 178-223.

Kennedy B. 1981. Marriage patterns in an archaic population: a study of skeletal remains from Port au Choix, Newfoundland. Ottawa: National Museum of Canada.

Kincaid C. 1984. Chaco roads project phase I: a reappraisal of prehistoric roads in the San Juan Basin. Santa Fe and Albuquerque: Bureau of Land Management, New Mexico State Office and Albuquerque District Office.

Konigsberg LW. 1987. Population genetic models for interpreting prehistoric intra-cemetery biological variation. Unpublished Ph.D. dissertation, Department of Anthropology, Northwestern University.

Konigsberg LW. 1988. Migration models of prehistoric postmarital residence. Am J Phys Anthropol 77:471-482.

Konigsberg LW, Buikstra JE. 1995. Regional approaches to the investigation of past human biocultural structure. In: Beck LA, editor. Regional approaches to mortuary analysis. New York: Plenum Press. p 191-219.

Konigsberg LW, Ousley SD. 1995. Multivariate quantitative genetics of anthropometric traits from the Boas data. Hum Biol 67:481-498.

Kowalski CJ. 1972. A commentary on the use of multivariate statistical methods in anthropometric research. Am J Phys Anthropol 36:119-132.

Lane RA, Sublett AJ. 1972. Osteology of social organization: residence pattern. Am Antiq 37:186-201.

Lekson SH. 1984. Standing architecture at Chaco Canyon and the interpretation of local and regional organization. In: Judge WG, Schelberg JD, editors. Recent research on Chaco prehistory. Reports of the Chaco Center no. 8. Albuquerque: Division of Cultural Research, National Park Service. p 55-73.

Lekson SH. 1986. Great pueblo architecture of Chaco Canyon, New Mexico. Albuquerque: University of New Mexico Press.

Lekson SH. 1988. Sociopolitical complexity at Chaco Canyon, New Mexico. Unpublished Ph.D. dissertation, Department of Anthropology, University of New Mexico, Albuquerque.

Lekson SH. 1999. The Chaco meridian: centers of political power in the ancient Southwest. Walnut Creek, CA: Alta Mira Press.

Lewis TMN, Lewis MK. 1961. Eva: an archaic site. Knoxville: University of Tennessee Press. 
Lischka JJ. 1975. Broken K revisited: a short discussion of factor analysis. Am Anthropol 40:220-227.

Lister RH, Lister FC. 1978. Anasazi pottery, ten centuries of prehistoric ceramic art in the Four Corners country of the southwestern United States. Albuquerque: Maxwell Museum of Anthropology, University of New Mexico Press.

Longacre WA. 1964. Sociological implications of ceramics analysis. Fieldiana Anthropol 55:155-170.

Longacre WA. 1966. Changing patterns of social integration: a prehistoric example from the American Southwest. Am Anthropol 68:94-102.

Longacre WA. 1968. Some aspects of prehistoric society in eastcentral Arizona. In: Binford S, Binford L, editors. New perspectives in archaeology. Chicago: Aldine. p 89-102.

Manly BFJ. 1994. Multivariate statistical methods: a primer, 2nd ed. London: Chapman \& Hall.

Martin PS, Plog F. 1973. The archaeology of Arizona, a study of the Southwest region. New York: Doubleday.

Martin R, Saller K. 1957. Lehrbuch der Anthropologie, Volume 1. Stuttgart: Gustav Fischer.

Mathien FJ. 1997. Ornaments of the Chaco Anasazi. In: Mathien FJ, editor. Ceramic, lithics, and ornaments of Chaco Canyon, volume III. Chaco Canyon studies, publications in archaeology. Santa Fe: National Park Service. p 1119-1220.

Mathien FJ. 2001. Anthropology and archaeology in Chaco Canyon, the Hyde exploring expedition. In: Wiseman RN, O'Laughlin TC, Snow CT, editors. Following through, papers in honor of Phyllis S. Davis. Papers of the Archaeological Society of New Mexico, volume 27. Albuquerque: Archaeological Society of New Mexico. p 103-114.

McPherron A. 1967. On the sociology of ceramics: Pottery style clustering, marital residence, and cultural adaptations of an Algonkian-Iroquoian border. In: Tooker E, editor. Iroquois culture history and prehistory. Proceedings of the 1965 Conference on Iroquois Research. Albany: University of the State of New York. p 101-107.

Montgomery DC. 1991. Design and analysis of experiments. New York: John Wiley \& Sons.

Neves WA. 1984. Paleogenetica dos grupos pre-historicos do litoral sul do Brasil (Parana e Santa Catarina). Unpublished Ph.D. dissertation, Department of Anthropology, University of Sao Paulo.

Nials F, Stein J, Roney J. 1987. Chacoan roads in the southern periphery: results of phase II of the BLM Chaco roads project. Cultural resource series no. 1. Santa Fe: New Mexico State Office, Bureau of Land Management.

Ortiz A. 1969. The Tewa world. Chicago: University of Chicago Press.

Ortner DJ, Putschar WGJ. 1981. Identification of pathological conditions in human skeletal remains. Smithsonian contributions to anthropology. Washington, DC: Smithsonian Institution Press.

Palkovich AM. 1980. Pueblo population and society: the Arroyo Hondo skeletal and mortuary remains. Arroyo Hondo archaeological series, volume 3. Santa Fe: School of American Research.

Palkovich AM. 1984. Disease and mortality patterns in the burial rooms of Pueblo Bonito: preliminary considerations. In: Judge JW, Schelberg JD, editors. Recent research on Chaco prehistory. Albuquerque: Division of Cultural Research, National Park Service. p 103-113.

Pepper GR. 1909. The exploration of a burial room in Pueblo Bonito, New Mexico. In: his friends and associates, contributors. Putman anniversary volume. New York: G.E. Stechert. p $196-252$

Pepper GR. 1920. Pueblo Bonito. American Museum of Natural History anthropological papers no. 27. New York: American Museum of Natural History.

Peregrine PN. 2001. Matrilocality, corporate strategy, and the organization of production in the Chacoan world. Am Antiq $66: 36-46$.

Peregrine PN, Ember M. 2002. Response to Schillaci and Stojanowski. Am Antiq 67:357-359.
Pierson LM. 1949. The prehistoric population of Chaco Canyon, New Mexico: a study in methods and techniques of prehistoric population estimation. Unpublished Master's thesis, Department of Anthropology, University of New Mexico, Albuquerque.

Plog S. 1978. Social interaction and stylistic similarity: a reanalysis. Adv Archaeol Method Theor 1:143-182.

Powers RP. 1984. Regional interaction in the San Juan Basin: the Chacoan outlier system. In: Judge WG, Schelberg JD, editors. Reports of the Chaco Center no. 8. Albuquerque: Division of Cultural Research, National Park Service. p 23-36.

Raemsch CA. 1995. Craniometric variation within skeletal samples of diverse biological composition. Unpublished Ph.D. dissertation, Department of Anthropology, State University of New York-Albany.

Relethford JH, Blangero J. 1990. Detection of differential gene flow from patterns of quantitative variation. Hum Biol 62:5-25.

Relethford JH, Crawford MH, Blangero J. 1997. Genetic drift and gene flow in post-famine Ireland. Hum Biol 69:443-465.

Reyman JE. 1971. Mexican influence on southwestern ceremonialism. Unpublished Ph.D. dissertation, Department of Anthropology, Southern Illinois University.

Rightmire GP. 1970. Iron age skulls from southern Africa reassessed by multiple discriminant analysis. Am J Phys Anthropol 33:147-168.

Rogers AR. 1987. A model of kin-structured migration. Evolution 41:417-426.

Roney JR. 1992. Prehistoric roads and regional interaction in the Chacoan system. In: Doyel DE, editor. Anasazi regional organization and the Chaco system. Maxwell Museum anthropological papers no. 5. Albuquerque: Maxwell Museum. p 123-131.

SAS, Inc. 1989. STAT user's guide, version 6, 4th ed. Cary, NC: SAS Institute, Inc.

Schelberg JD. 1984. Analogy, complexity and regionally-based perspectives. In: Judge WG, Schelberg JD, editors. Recent research on Chaco prehistory. Reports of the Chaco Center no. 8. Albuquerque: Division of Cultural Research, National Park Service. p 5-21.

Schillaci MA, Stojanowski CM. 2000. Postmarital residence and population structure at Pueblo Bonito. Am J Phys Anthropol [Suppl] 30:271 [abstract].

Schillaci MA, Stojanowski CM. 2002. A reassessment of matrilocality in Chacoan culture. Am Antiq 67:343-356

Schillaci MA, Ozlins EG, Windes TC. 2001. Multivariate assessment of biological relationships among prehistoric Southwest Amerindian populations. In: Wiseman RN, O'Laughlin TC, Snow CT, editors. Following through, papers in honor of Phyllis S. Davis. Papers of the Archaeological Society of New Mexico, volume 27. Albuquerque: Archaeological Society of New Mexico. p 133-149.

Sebastian L. 1991. Sociopolitical complexity and the Chaco system. In: Crown PL, Judge WJ, editors. Chaco and Hohokam, prehistoric regional systems in the American Southwest. Santa Fe: School of American Research. p 109-129.

Sebastian L. 1992. The Chaco Anasazi: sociopolitical evolution in the prehistoric Southwest. London: Cambridge University Press.

Seltzer CC. 1944. Racial history in the Southwest and the Hawikuh Zunis. Papers of the Peabody Museum of American Archaeology and Ethnology, volume 23. Cambridge, MA: Peabody Museum of American Archaeology and Ethnology.

Sjøvold T. 1984. A report on the heritability of some cranial measurements and non-metric traits. In: van Vark GN, Howells WW, editors. Multivariate statistical methods in physical anthropology. Dordrecht: D. Reidel Publishing Co. p 233-246.

Spence MW. 1971. Skeletal morphology and social organization in Teotihuacan, Mexico. Unpublished Ph.D. dissertation, Department of Anthropology, Southern Illinois University.

Spence MW. 1974a. Residential practices and the distribution of skeletal traits in Teotihuacàn, Mexico. Man 9:262-273.

Spence MW. 1974b. The study of residential practices among prehistoric hunters and gatherers. World Archaeol 5:346-357.

Stanislawski MB. 1973. Review of archaeology as anthropology: a case study. Am Antiq 38:117-122. 
Stefan VH. 1999. Craniometric variation and homogeneity in prehistoric/protohistoric Rapa Nui (Easter Island) regional populations Am J Phys Anthropol 110:407-419.

Steward J. 1937. Ecological aspects of southwestern society. Anthropos 32:87-104.

Susanne C. 1977. Heritability of anthropological characters. Hum Biol 49:573-580.

Toll HW. 1985. Pottery, production, public architecture and the Chaco Anasazi system. Unpublished Ph.D. dissertation, Department of Anthropology, University of Colorado.

Toll WH, McKenna PJ. 1997. Chaco ceramics. In: Mathien FJ, editor. Ceramics, lithics and ornaments of Chaco Canyon. Publications in archaeology 18G, Chaco Canyon studies. Santa Fe: National Park Service, US Department of the Interior. p 17530.

Trager GL. 1967. The Tanoan settlement of the Rio Grande area: a possible chronology. In: Hymes DH, Bittle WE, editors. Meaning and history of the languages of the American Southwest. The Hague: Mouton. p 335-350.

Turner CG II. 1993. Cannibalism in Chaco Canyon: the charnel pit excavated in 1926 at Small House Ruin by Frank H.H. Roberts, Jr. Am J Phys Anthropol 91:421-439.

Turner CG II, Lofgren L. 1966. Household size of prehistoric western Pueblo Indians. Southwest J Anthropol 22:117-132.

Turner CG II, Turner JA. 1999. Man corn, cannibalism and violence in the prehistoric American Southwest. Salt Lake City: University of Utah Press.

Vivian G. 1956. Review of the material culture of Pueblo Bonito, by N.M. Judd. Am Antiq 21:322-324.

Vivian RG. 1970. Aspects of prehistoric society in Chaco Canyon, New Mexico. Unpublished Ph.D dissertation, Department of Anthropology, University of Arizona, Tucson.

Vivian RG. 1989. Kluckhohn reappraised: the Chacoan system as an egalitarian enterprise. J Anthropol Res 45:101-113.

Vivian RG. 1990. The Chacoan prehistory of the San Juan Basin. San Diego: Academic Press.
Vivian RG. 1997a. Chacoan roads: morphology. Kiva 63:7-34.

Vivian RG. 1997b. Chacoan roads: function. Kiva 63:35-67.

Von Endt DW, Ortner DJ. 1982. Amino acid analysis of bone from a possible case of prehistoric iron deficiency anemia from the American Southwest. Am J Phys Anthropol 59:377-385.

Ware JA. 2001. Chaco social organization, a peripheral view. In: Cordell LS, Judge WJ, Piper J, editors. Chaco Society and polity: Papers from the 1999 conference. New Mexico Archaeological Council special publication 4. Albuquerque: New Mexico Archaeological Council. p 79-93.

Ware JA, Blinman E. 2000. Cultural collapse and reorganization: the origin and spread of Pueblo ritual organizations. In: Hegmon M, editor. The archaeology of regional interaction: religion, warfare, and exchange across the American Southwest and beyond. Boulder: University Press of Colorado. p 381-409.

Whallon R. 1968. Investigations of late prehistoric social organization in New York. In: Binford S, Binford L, editors. New perspectives in archaeology. Chicago: Aldine. p 223-244.

White TD, Folkens PA. 2000. Human osteology. San Diego: Academic Press.

Williams-Blangero S. 1987. Clan-structured migration and microdifferentiation in a Himalayan population. Am J Phys Anthropol 72:270.

Williams-Blangero S. 1989. Clan-structured migration and phenotypic differentiation in the Jirels of Nepal. Hum Biol 61:143157.

Williams-Blangero S, Blangero J. 1989. Anthropometric variation and the genetic structure of the Jirels of Nepal. Hum Biol $61: 1-12$.

Windes TC. 1984. A new look at population in Chaco Canyon. In: Judge WG, Schelberg JD, editors. Recent research on Chaco prehistory. Reports of the Chaco Center no. 8. Albuquerque: Division of Cultural Research, National Park Service. p 75-87.

Windes TC, Ford D. 1996. The Chaco wood project: the chronometric reappraisal of Pueblo Bonito. Am Antiq 61:295-310.

Wright JV. 1966. Michipicoten site. Natl Mus Can Bull 224:1-85. 